\title{
Yeast-specific DNA probes and their application for the detection of Candida albicans
}

\author{
A. R. HOLMES, Y. C. LEE, R. D. CANNON, H. F. JENKINSON and M. G. SHEPHERD
}

Department of Oral Biology and Pathology, School of Dentistry, University of Otago, PO Box 647, Dunedin, New Zealand

\begin{abstract}
Summary. Two DNA fragments cloned from the genome of Candida albicans ATCC 10261 may be useful in the rapid diagnosis of disseminated candidosis. One sequence (probe EOB1) was specific for $C$. albicans (positive hybridisation with 45 strains tested). The second sequence (probe EOB2) detected C. albicans, as well as five other pathogenic Candida spp. and Saccharomyces cerevisiae, but did not react with human or bacterial DNA. Both probes were repetitive sequences in the genome of $C$. albicans. Probe EOB1 was used to detect, without DNA amplification, 500 C. albicans yeast cells in $1 \mathrm{ml}$ of human blood.
\end{abstract}

\section{Introduction}

Haematogenous disseminated candidosis is increasingly common in immunosuppressed and postoperative patients. ${ }^{1,2}$ Figures from the University of Iowa Hospitals and Clinics showed that by the late 1980s, Candida spp. comprised $10 \%$ of all nosocomial blood-culture isolates at a rate of 8.5 infections $/ 10000$ admissions. ${ }^{3}$ This study reported an attributable mortality rate of $26-49 \%$, that reflects the considerable susceptibility of certain "at risk" groups. Treatment of this life-threatening condition is often delayed until the infection is identified because the antifungal drugs used are toxic; yet there is a much improved prognosis if antifungal therapy is begun promptly. ${ }^{4}$ DNA-based diagnostic tests have the potential to reduce the time for laboratory identification of pathogens that are slow-growing or difficult to culture. The development of a specific and sensitive DNA probe for Candida spp., in particular $C$. albicans, would enable more rapid detection of yeasts in blood or biopsy samples.

Several C. albicans-specific DNA sequences have been isolated. These include both unique sequences such as the cytochrome $\mathrm{P}_{450}$ gene, ${ }^{4}$ and repetitive sequences, ${ }^{5-8}$ which have been used as probes in epidemiological studies. ${ }^{9,10}$ The only sequence that has been used to identify $C$. albicans in clinical specimens is the $P_{450}$ probe. ${ }^{4}$ Because this gene is present at a single copy locus in C. albicans, it was necessary to use polymerase chain reaction (PCR) amplification of target DNA.

We describe two fragments of repetitive DNA isolated from $C$. albicans. One contains a C. albicansspecific sequence and the other contains a sequence that is present in several Candida spp.

\section{Materials and methods}

\section{Bacteria and yeast strains}

Escherichia coli strain C600 (supE44, tonA21, thr-1, leuB6, thi-1, lacY1, str ${ }^{R}$ ) and E. coli JM83 (Alacpro, ara, thi, str $A, \phi 80 \mathrm{~d} l a c Z \Delta \mathrm{M} 15)$ were used as bacterial hosts for propagation of plasmids. The strains of C. albicans, other Candida spp., and Saccharomyces cerevisiae used are listed in table I. All clinical isolates were identified by the Microring YT system (Medical Wire and Equipment Co.) and all $C$. albicans strains formed germ-tubes when incubated in serum. The identities of all Candida strains used were confirmed by the use of an immune agglutination identification system, IATRON ${ }^{\circledR}$ (Iatron Laboratories, Tokyo, Japan) which also allowed serotyping of $C$. albicans strains. C. albicans laboratory strains MEN and A72 and nine of the clinical isolates were serotype $B$, all other $C$. albicans strains were serotype A. Yeast strains were propagated on yeast peptone dextrose (YPD) agar containing, /L, yeast extract $3 \mathrm{~g}$, bactopeptone $10 \mathrm{~g}$, glucose $20 \mathrm{~g}$ and agar $15 \mathrm{~g}$, and stocks were maintained at $-80^{\circ} \mathrm{C}$ in YPD containing glycerol $15 \%$.

\section{DNA purification}

RNA-free DNA was prepared from C. albicans and other yeasts by the method of Cryer et al., ${ }^{11}$ but was not purified by centrifugation through $\mathrm{CsCl}$. Spheroplasts were formed by treatment with zymolyase $(20 \mu \mathrm{g} / \mathrm{g}$ wet weight of cells) and lysed with SDS. Protein was removed by proteinase $\mathrm{K}(1 \mathrm{mg} / \mathrm{ml})$ and RNA by RNAase $(10 \mu \mathrm{g} / \mathrm{ml})$ treatment and further protein and lipid by chloroform-isoamyl alcohol extraction before sequential ethanol precipitations. Human DNA was purified from peripheral blood 
Table I. Yeast strains used in the study

\begin{tabular}{|c|c|c|}
\hline Species & Strain no. & Source \\
\hline \multirow[t]{8}{*}{ C. albicans } & 10261 & ATCC \\
\hline & 3153 & NCPF \\
\hline & A72 & A. Cassone (Instituto Superiore di Sanita, Rome, Italy) \\
\hline & MEN & D. Kerridge (Biochemistry Dept, Cambridge University) \\
\hline & 473 & Laboratory strain \\
\hline & $85 / 031$ & F. C. Odds (Janssen Research Foundation, Beerse, Belgium) \\
\hline & SGY-243 & R. Kelly (Merck and Co., Rahway, NJ, USA) \\
\hline & $\begin{array}{l}\text { Ci 001-007; 009-013; } \\
015-042\end{array}$ & Dunedin Public Hospital and School of Dentistry, Otago University, NZ \\
\hline \multirow[t]{4}{*}{ C. tropicalis } & Ci $008 ; 014 ; 043 ; 046$ & Dunedin Public Hospital and School of Dentistry, Otago University, NZ \\
\hline & 13803 & ATCC \\
\hline & MY 820738 & NZ Communicable Disease Centre, Porirua \\
\hline & MY 820567 & NZ Communicable Disease Centre, Porirua \\
\hline \multirow[t]{4}{*}{ C. krusei } & 89.102 & NZ Communicable Disease Centre, Porirua \\
\hline & 90.147 & NZ Communicable Disease Centre, Porirua \\
\hline & 89.021 & NZ Communicable Disease Centre, Porirua \\
\hline & 89.221 & NZ Communicable Disease Centre, Porirua \\
\hline \multirow[t]{4}{*}{ C. parapsilosis } & 90.493 & NZ Communicable Disease Centre, Porirua \\
\hline & 90.454 & NZ Communicable Disease Centre, Porirua \\
\hline & 90.111 & NZ Communicable Disease Centre, Porirua \\
\hline & 90.463 & NZ Communicable Disease Centre, Porirua \\
\hline \multirow[t]{4}{*}{ C. kefyr } & 78.1161 & NZ Communicable Disease Centre, Porirua \\
\hline & 82.656 & NZ Communicable Disease Centre, Porirua \\
\hline & Colindale & NZ Communicable Disease Centre, Porirua \\
\hline & 78.256 & NZ Communicable Disease Centre, Porirua \\
\hline \multirow{4}{*}{ C. guilliermondii } & 85.791 & NZ Communicable Disease Centre, Porirua \\
\hline & 85.739 & NZ Communicable Disease Centre, Porirua \\
\hline & 86.117 & NZ Communicable Disease Centre, Porirua \\
\hline & 89.140 & NZ Communicable Disease Centre, Porirua \\
\hline \multirow{2}{*}{ S. cerevisiae } & $\mathrm{C} 31 \mathrm{C}$ & C. Nombela (Universidad Complutense, Madrid, Spain) \\
\hline & DYC & Laboratory strain \\
\hline
\end{tabular}

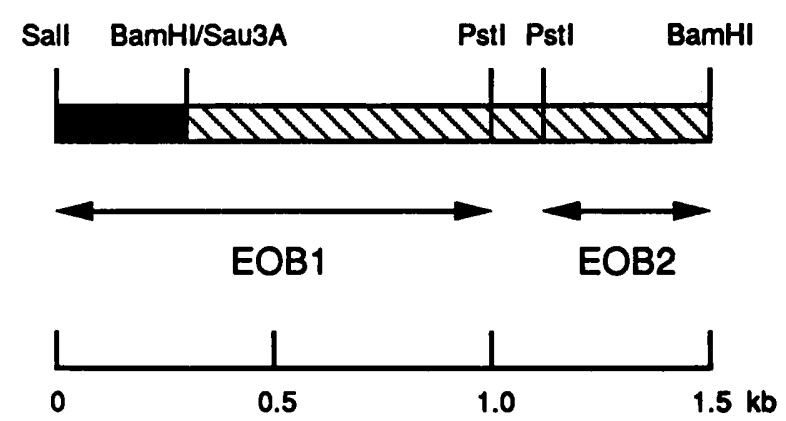

Fig. 1. Derivation of probes EOB1 and EOB2 from C. albicans DNA $(\mathbb{\nabla})$ inserted into pMK $155 .{ }^{11}$ Probe EOB1 $(1 \mathrm{~kb})$ contained a region (a) of the tetracycline resistance gene $\left(\mathrm{Tc}^{\mathrm{R}}\right)$ of $\mathrm{pMK} 155$ (from pBR328).

lymphocytes as described by Herrmann and Frischauf. ${ }^{12}$ DNA concentrations of purified preparations were estimated by measuring absorbance at $260 \mathrm{~nm}$.

\section{DNA probes}

C. albicans ATCC 10261 chromosomal DNA was digested with the restriction endonuclease $E c o$ RI and ligated into EcoRI-digested pMK $155,{ }^{13}$ a plasmid which contained the bla (ampicillin resistance) gene for selection in $E$. coli, and the $C$. albicans 3isopropylmalate dehydrogenase (LEU2) gene. A plasmid was obtained which replicated autonomously in S. cerevisiae ${ }^{14}$ and plasmid DNA was prepared with a Plasmid Quik ${ }^{\circledR}$ kit (Stratagene Corporation, La
Jolla, CA, USA). After reducing the size of inserted DNA by subcloning, a plasmid was obtained which contained $1.2 \mathrm{~kb}$ of $C$. albicans DNA. Two DNA fragments from this plasmid comprised two of the probes used in this study (fig. 1). Probe EOBI was a 1$\mathrm{kb}$ fragment that hybridised to $C$. albicans but not to $S$. cerevisiae genomic DNA. An adjacent DNA fragment of $0.38 \mathrm{~kb}$ (denoted EOB2) hybridised to both $C$. albicans and to $S$. cerevisiae genomic DNA. The fragments were subcloned into pUC19 and were excised, and labelled with either $\left[\alpha^{35} \mathrm{~S}\right] \mathrm{dATP} \alpha \mathrm{S}$ by nick translation, ${ }^{15}$ (50-100 ng DNA) or with peroxidase by the ECL (Amersham International) procedure (200 ng DNA). Probe EOB1 contained a small portion $(300 \mathrm{bp})$ of the tetracycline resistance gene from pBR328, as well as $C$. albicans genomic DNA. In separate experiments, the pBR328 DNA did not hybridise with any of the bacterial or yeast DNA preparations tested. A third probe (EOB3) consisted of a 2.2-kb EcoRI-BamHI fragment of $C$. albicans DNA, which was excised from plasmid pMK $155,{ }^{13}$ and contained the complete coding region for the C. albicans LEU2 gene.

\section{Preparation of dot-blots}

Yeasts were grown at $30^{\circ} \mathrm{C}$ on YPD agar for $18 \mathrm{~h}$ and cells from the surface of the plate were suspended in sterile deionised water at a concentration of $10^{8}$ cells $/ \mathrm{ml}$. In a microcentrifuge tube, a $20-\mu 1$ portion 
of this suspension was mixed with $1 \mathrm{M}$ sorbitol containing $10 \mathrm{~mm}$ EDTA $(0 \cdot 2 \mathrm{ml})$. Zymolyase-100T (10 $\mu$, $2 \mathrm{mg} / \mathrm{ml}$; Seikagaku Kogyo, Tokyo, Japan) was added and the suspension was incubated for $2 \mathrm{~h}$ at $37^{\circ} \mathrm{C}$ to produce spheroplasts. These were lysed by the addition of N-lauroylsarcosinate $20 \% \mathrm{w} / \mathrm{v}(12 \mu \mathrm{l}, \mathrm{pH} 8.0)$ in the presence of proteinase $\mathrm{K}(25 \mu \mathrm{l}, 10 \mathrm{mg} / \mathrm{ml})$ and $0.4 \mathrm{M}$ EDTA $(50 \mu \mathrm{l}, \mathrm{pH} 8.0)$ and incubated for $2 \mathrm{~h}$ at $50^{\circ} \mathrm{C}$. Portions $(0.1 \mathrm{ml})$ of the DNA extracts were added to the wells of a dot-blot manifold containing Hybond $\mathrm{N}^{+}$membrane (Amersham International) and incubated with $0.1 \mathrm{ml}$ of $1 \mathrm{M} \mathrm{NaOH}$ for $20 \mathrm{~min}$ before applying a vacuum $(\approx 15 \mathrm{kPa})$. Blots were washed $(2 \mathrm{~min})$ in $1 \mathrm{M}$ ammonium acetate (pH 5.5) and in $2 \times$ saline sodium citrate $(1 \times$ SSC: $0.15 \mathrm{M} \mathrm{NaCl}, 15 \mathrm{mM}$ trisodium citrate, $\mathrm{pH} 7.0$ ), before being used in hybridisation experiments.

\section{Hybridisation conditions}

For probes labelled with ${ }^{35} \mathrm{~S}$, the hybridisation solution contained $5 \times$ Denhardts solution $(50 \times$ Denhardts: BSA $1 \% \mathrm{w} / \mathrm{v}$, Ficoll ${ }^{\otimes} 1 \% \mathrm{w} / \mathrm{v}$ [Pharmacia, Uppsala, Sweden], polyvinylpyrollidone $1 \% \mathrm{w} / \mathrm{v}$ in $6 \times$ SSC), $6 \times$ SSC and SDS $0.5 \% \mathrm{w} / \mathrm{v}$. Blots were pre-hybridised for $3 \mathrm{~h}$ at $68^{\circ} \mathrm{C}$ and then incubated with radiolabelled probe $(100 \mathrm{ng}$, specific activity $1 \times 10^{8} \mathrm{dpm} / \mu \mathrm{g}$, denatured by boiling in $0.2 \mathrm{M}$ $\mathrm{NaOH}$ for $2 \mathrm{~min}$ ) for $16 \mathrm{~h}$ at $68^{\circ} \mathrm{C}$ in the presence of herring sperm DNA $(0.1 \mathrm{mg} / \mathrm{ml})$. High stringency washes were for $2 \mathrm{~h}$ at $65^{\circ} \mathrm{C}$ in $0.1 \times \mathrm{SSC}$ containing SDS $0.5 \%$ (allowing $<10 \%$ mismatch), and low stringency washes were for $2 \mathrm{~h}$ at $50^{\circ} \mathrm{C}$ in $6 \times \mathrm{SSC}$ containing SDS $0.5 \%$ (allowing c. $30 \%$ mismatch).

For ECL ${ }^{\otimes}$ peroxidase-labelled probes, the hybridisation and post-hybridisation wash conditions recommended by the manufacturers were followed, with the inclusion of $0.5 \mathrm{M} \mathrm{NaCl}$ in the hybridisation solution.

\section{Separation of candida cells from whole blood}

Whole blood from volunteers was collected into Vacutainer tubes containing EDTA $10.5 \mathrm{mg}$ as anticoagulant and yeast cells of $C$. albicans MEN were added at known concentrations-range $\left(5 \times 10^{5}\right)$ 50 cells $/ \mathrm{ml}$. Cell suspensions were vortex mixed before inoculating blood samples and cells were fully dispersed when viewed by phase contrast microscopy. Blood (1 ml), containing yeast cells, was layered on to $0.3 \mathrm{ml}$ of Percoll (Pharmacia) $70 \%$ in phosphatebuffered saline (PBS, containing, /L, $\mathrm{NaCl} 8.5 \mathrm{~g}$, $\mathrm{Na}_{2} \mathrm{HPO}_{4} 0.85 \mathrm{~g}, \mathrm{KH}_{2} \mathrm{PO}_{4} 0.54 \mathrm{~g}$ ) and centrifuged at $7500 \mathrm{~g}$ for $10 \mathrm{~min}$ at room temperature. The top layer was removed and the Percoll ${ }^{\circledast}$ containing the yeast cell pellet was diluted with an equal volume of distilled water. The pellet was washed once by centrifugation and resuspended in water for determination of viable cell numbers (see below), and extraction of DNA as described above. The proportion of the initial inoculum recovered by this method was determined by viable plate counts or by total cell counts with a haemocytometer. To measure viable counts, appropriately diluted portions $(0.1 \mathrm{ml})$ of inoculum, or of recovered pellet, were spread on YPD plates which were then incubated for $16 \mathrm{~h}$ at $30^{\circ} \mathrm{C}$.

\section{Results}

Probes EOB1 and EOB2 were derived from the genome of $C$. albicans ATCC 10261. To test the hybridisation specificity of these probes, genomic DNA was extracted from a number of yeast strains. DNA preparations were immobilised on to nylon membrane as dot-blots, and the membranes were incubated with ${ }^{35} \mathrm{~S}$-labelled probe EOB1 or EOB2. Probe EOB1 hybridised with genomic DNA from all C. albicans strains examined (11 serotype B and 34 serotype A), but not with DNA from 23 strains representative of five other Candida spp. even at the lower stringency conditions. In contrast, probe EOB2 hybridised with DNA preparations from all Candida strains tested, with duplicate blots of the same genomic DNA preparations used for the EOB1 hybridisations (table II). Fig. 2 shows the comparative hybridisation of probes EOB1 and EOB2 to duplicate blots of DNA from representative strains of all the Candida spp. tested. At the high stringency conditions used, probe EOB2 gave a stronger hybridisation signal with C. albicans strains than with other Candida spp. This was less marked if lower stringency conditions of hybridisation were used. Probe EOB2 also reacted with $S$. cerevisiae DNA.

In all these experiments, DNA was extracted from an equivalent number of cells for each species, yeast cell samples were completely lysed by the DNA extraction procedure, and probes EOB1 and EOB2 were used with duplicate blots. Neither probe hybridised to dot-blots of human lymphocyte DNA nor to DNA from several bacteria, including Streptococcus sanguis, Listeria monocytogenes and $E$. coli, even with $0.2 \mu \mathrm{g}$ of purified DNA/dot-blot. However, hybrid-

Table II. Hybridisation of ${ }^{35}$ S-labelled DNA probes with genomic DNA from laboratory strains and clinical isolates of Candida spp.

\begin{tabular}{l|ccc}
\hline & & \multicolumn{3}{c}{$\begin{array}{c}\text { Number of strains positive } \\
\text { with probe }\end{array}$} \\
& \multicolumn{1}{c|}{$\begin{array}{c}\text { Number of } \\
\text { Strains tested }\end{array}$} & EOB1 & EOB2 \\
\cline { 3 - 4 } Species & & & \\
Laboratory strains & 7 & 7 & 7 \\
C. albicans & 3 & 0 & 3 \\
C. tropicalis & 4 & 0 & 4 \\
C. parapsilosis & 4 & 0 & 4 \\
C. kefyr & 4 & 0 & 4 \\
C. krusei & 4 & 0 & 4 \\
C. guilliermondii & & & 38 \\
Clinical isolates & 38 & 38 & 4 \\
C. albicans & 4 & 0 & \\
C. tropicalis & & & \\
\hline
\end{tabular}




\section{EOB1 EOB2
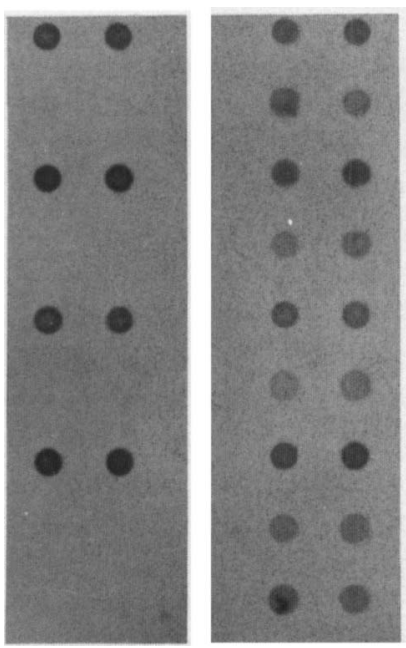 \\ C.albicans MEN \\ C.tropicalis $\mathrm{CiO} 014$ \\ C.albicans 10261 \\ C.parapsilosis 90.463 \\ C.albicans $\mathrm{CiO07}$ \\ C.kefyr 78.256 \\ C.albicans Ci 036 \\ C.guilliermondii 86.117 \\ C.krusei 89.102}

Fig. 2. Dot-blots showing specificities of ${ }^{35} \mathrm{~S}$ dATP-labelled probes EOB1 and EOB2 for genomic DNA extracted from equivalent cell concentrations of four C. albicans strains and single representative strains of five other Candida spp. High stringency conditions were used.

C.a. C.p. C.k. C.a. $1026190.463 \quad 78.256$ MEN
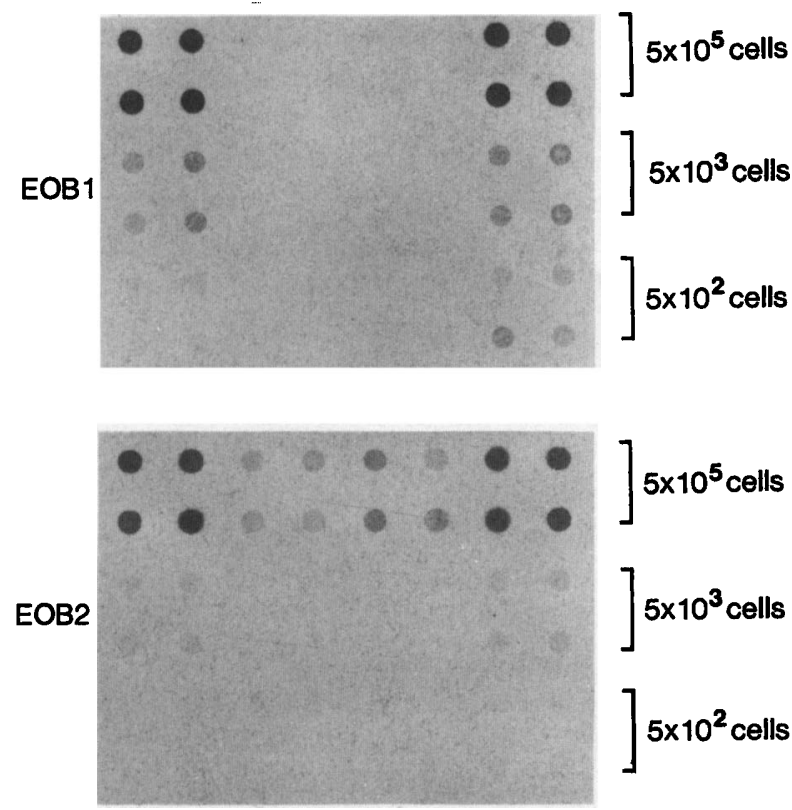

Fig. 3. Hybridisation of ${ }^{35} \mathrm{~S}$ dATP-labelled probes EOB1 and EOB2 to duplicate dot-blots of genomic DNA extracted from different cell concentrations of two strains of C. albicans (10261 and MEN), one strain of C. parapsilosis (90.463) and one strain of C. kefyr (78.256). High stringency conditions were used.

isation of probe EOB1 to C. albicans genomic DNA was clearly detectable with dot-blots of $200 \mathrm{pg}$ of purified DNA (results not shown).

Thus, a high sensitivity of probe EOB 1 to $C$. albicans DNA was indicated by the titration of purified C. albicans genomic DNA. If either probe was to be considered for the direct detection of yeast cells in clinical specimens, it would be necessary to recover and to detect low numbers of organisms. To determine the limit of detection of the probes, known concentrations of yeast cells were serially diluted in sterile deionised water and DNA was extracted from the cells present in 20- $\mu$ l samples. DNA extraction, immobilisation on nylon membrane and hybridisation procedures were carried out as before. Under high stringency conditions, probe EOB1 gave a positive hybridisation signal with DNA extracted from a diluted cell sample containing $5 \times 10^{2}$ cells, but not from a 10-fold lower dilution, with the two C. albicans strains tested (fig. 3). Probe EOB2 was less sensitive for $C$. albicans DNA; the detection limit was $5 \times 10^{3}$ cells at the high stringency used (fig. 3), and it was even less sensitive for $C$. parapsilosis and $C$. kefyr, with detection limits of $5 \times 10^{5}$ cells. When a nonradioactive probe-labelling system was used, both probes demonstrated the same pattern of specificity as the radiolabelled probes, but the sensitivities were between 10- and 100-fold lower.

The usefulness of a DNA probe as a diagnostic tool is determined by the ability to detect DNA from low numbers of the target organism in clinical specimens, as well as by probe specificity and sensitivity. Probe EOB1 was used to investigate the detection of C. albicans cells and DNA in whole human blood inoculated with yeast cells. A method was developed, similar in principle to the lysis centrifugation method, ${ }^{16}$ that allowed yeast cells to be recovered and concentrated, with minimal contaminating blood material. $C$. albicans cells could be sedimented by centrifugation through Percoll ${ }^{\otimes} \%$ whereas blood cells could not. Thus, blood inoculated with C. albicans was layered on a cushion of Percoll $75 \%$ and yeast cells were separated as described in Materials and methods. The yeast cells were counted or subjected to DNA extraction procedures. The recovery of yeast cells (as determined by viable count or microscopic observation) was $70-80 \%$. With this method and probe EOB1, it was possible to detect $C$. albicans DNA from $5 \times 10^{2}$ cells in $1 \mathrm{ml}$ of blood.

The following experiment was devised to estimate the number of copies of the EOB 1 probe sequence in the $C$. albicans genome by comparison with a sequence (LEU2) known to be present at a single locus. ${ }^{14} \mathrm{~A}$ plasmid was constructed that contained both the EOB1 and EOB3 ( $L E U 2$ ) sequences; the hybridisation of either probe EOB1 or EOB3 sequences to duplicate dot-blot titrations of both the plasmid, containing single copies of these sequences, and of genomic DNA extracted from known numbers of $C$. albicans cells was compared. Plasmid DNA and yeast cells of $C$. albicans MEN were each serially diluted, and after extraction of DNA from the cell samples, the DNA preparations were dot-blotted on to duplicate membranes. The concentration of plasmid DNA was determined spectrophotometrically before dilution and dot-blotting. Each duplicate membrane was hybridised with either peroxidase-labelled probe EOB 1 or EOB3, and probe bound to blots was detected by chemilumin- 


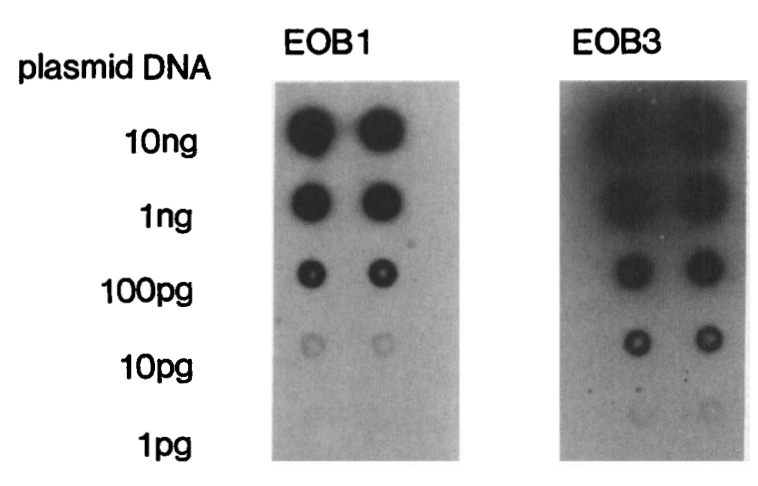

genomic DNA
$3.0 \times 10^{5}$ cells
$1.0 \times 10^{5}$ cells
$3.3 \times 10^{4}$ cells
$1.1 \times 10^{4}$ cells
$3.6 \times 10^{3}$ cells
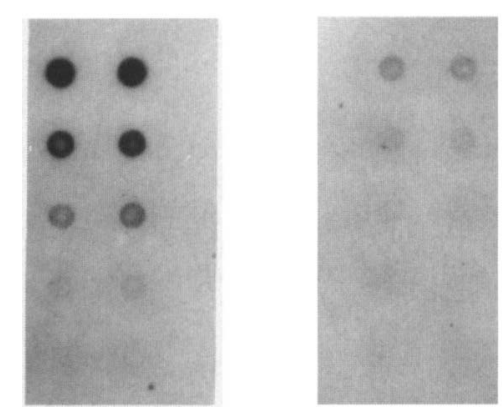

Fig. 4. Comparison of the hybridisation of peroxidase-labelled probes EOB1 and EOB3 ( $L E U 2$ gene probe) to duplicate dot-blots of DNA at different concentrations from a plasmid containing both probe sequences and to genomic DNA extracted from different cell concentrations of $C$. albicans strain MEN. Bound probe was detected by chemiluminescence.

escence. Peroxidase labelling was used because the technique was simpler than radiolabelling, and we had previously shown that probe specificity was maintained. Although a degree of sensitivity was lost (10-100-fold under the conditions used), this did not affect interpretation of comparative experiments. Fig. 4 shows that both probes EOB1 and EOB3 hybridised with the titrated plasmid DNA. However, the hybridisation signal of probe EOB3 was stronger than that of probe EOB1; probe EOB3 showed a limit of sensitivity of $0.1-1.0 \mathrm{pg}$ whereas probe EOB1 detected 1-10 pg of plasmid DNA. In contrast, the reactivity of probe EOB1 with the genomic DNA titration was stronger than that of probe EOB3, detecting DNA extracted from $\leqslant 1.1 \times 10^{4}$ cells in contrast to a limit of detection of $\leqslant 1.0 \times 10^{5}$ cells with probe EOB3. Thus, without allowing for the differing hybridisation signal strengths of the two probes, probe EOB 1 is at least 10-fold more sensitive for the detection of $C$. albicans genomic DNA than a probe to a single locus gene.

\section{Discussion}

With the advent of new antifungal drugs, the prospects for management of disseminated candidosis are improving, yet diagnosis remains difficult. Early recognition and treatment of disseminated disease is important, and a rapid test for circulating Candida cells would be a valuable aid to diagnosis. There is accumulating evidence that patients with only a single positive blood culture are at risk of subsequent systemic infection. However, it has been reported that blood cultures are often negative despite later evidence (often at autopsy) of systemic infection. This could reflect the fact that fungaemia may be only transient and the numbers of viable organisms low, thus limiting the effectiveness of detection by culture methods. However, negative blood cultures may result from the use of less than optimal culture procedures. ${ }^{17}$ The lysis centrifugation method of blood culture ${ }^{18}$ has been demonstrated to be superior for yeast isolation when compared with other commonly used systems. ${ }^{2,17}$ Furthermore, many circulating yeast cells may be noncultivable. The use of a DNA-based detection method, in combination with an adaptation of the lysis centrifugation method for enhanced cell recovery, has the potential to detect both viable and non-viable organisms.

Probe EOB1, described in this paper, was shown to detect specifically $C$. albicans DNA (table II and fig. 2). The specificity was $100 \%$ for 45 known strains of $C$. albicans compared with 23 strains of five other Candida spp. The absence of probe EOB1 hybridisation to genomic DNA from other yeast species was not due to inefficient extraction of DNA from the other yeasts because duplicate blots of yeast genomic DNAs did hybridise with a second probe, EOB2. Furthermore, known concentrations of purified DNA from yeasts other than $C$. albicans and also from human and bacterial cells did not hybridise with probe EOB1. Probe EOB2, that hybridised with all the yeast species tested, was less sensitive and may provide a suitable target for amplification by the PCR technique. Thus, it could have a role in the initial detection of fungaemia, in combination with species-specific probes such as EOB1.

Probe EOB1, labelled with ${ }^{35} \mathrm{~S}$ by nick translation, gave a sensitivity of detection of $5 \times 10^{2} C$. albicans cells, and this number of cells could be recovered and detected when inoculated into blood. This is within the range of cell counts in clinical fungaemia, ${ }^{18,19}$ although counts of $<100 \mathrm{cfu} / \mathrm{ml}$ are frequently encountered. ${ }^{18}$ For the probe to be of use diagnostically, it is probable that PCR amplification of the target DNA in blood samples will be required. However, if a significant proportion of circulating yeasts are non-viable in $C$. albicans fungaemias, direct detection with a multiple copy probe, such as EOB1, at low stringency may be feasible. A DNA probe for Trichomonas vaginalis has been used successfully to detect the organism directly in clinical specimens with a similar degree of sensitivity to that reported in the present study. ${ }^{20}$

The high sensitivity obtained with probe EOB 1 was shown to be due to the presence of multiple copies of the sequence in the genome by an experiment in which hybridisation to genomic DNA was compared with that of a probe present on the genome at a single locus (EOB3). The reactivity of probe EOB1 with genomic 
DNA from $C$. albicans was at least 10 -fold greater than that of EOB3, whereas the latter probe reacted more strongly with DNA from a plasmid containing a single copy of each of the sequences (fig. 4). The greater sensitivity of probe EOB3 with the plasmid DNA titration may reflect a greater efficiency of labelling by peroxidase of the larger probe (probe EOB3 was $2.2 \mathrm{~kb}$ whereas probe EOB1 was $1.0 \mathrm{~kb}$ ). Alternatively, differing base compositions of the two probes may have affected the relative hybridisation at the stringency used. If the difference in hybridisation to plasmid DNA of the two probes is taken into account, the hybridisation of probe EOB 1 with genomic DNA is in the order of 100 -fold greater than that with a single copy gene probe. The plasmid that was used in the titration series comprised $8.58 \mathrm{~kb}$ of DNA $\left(5.66 \times 10^{3} \mathrm{kDa}\right)$. The minimum amount of this plasmid that EOB3 could detect was $1 \mathrm{pg}$, which corresponded to $1.06 \times 10^{5}$ molecules (or copies) of the common sequence, the $L E U 2$ gene. The same probe could detect DNA from $1 \times 10^{5}$ cells indicating, within the accuracy of the experiment, the presence of the two copies of the LEU2 sequence that would be expected for one locus in a diploid cell. Extending this analysis to the hybridisation properties of probe EOB1, we observed a detection limit of $\leqslant 10 \mathrm{pg}$ with plasmid DNA as target. This corresponded to $1.06 \times 10^{6}$ molecules, and since the same probe hybridised with the DNA from $1 \cdot 1 \times 10^{4}$ cells, these results indicated the presence of $c .100$ copies of the EOB1 sequence/ cell. It is important to note that this method of determining copy number does not depend on the labelling efficiencies of the probes nor the absolute sensitivity of the probes.

In conclusion, we have identified a portion of $C$. albicans DNA which can be used as a highly specific and sensitive probe for $C$. albicans. With this probe and a simple separation technique, $C$. albicans present in blood at concentrations $\geqslant 500$ cells $/ \mathrm{ml}$ could be detected.

This study was supported in part by the Health Research Council of New Zealand and the New Zealand Emerging Technologies Board. Y.C.L. was in receipt of a New Zealand Dental Research Foundation Board Summer Studentship.

\section{References}

1. Musial CE, Cockerill FR, Roberts GD. Fungal infections of the immunocompromised host: clinical and laboratory aspects. Clin Microbiol Rev 1988; 1 : 349-364.

2. Jones JM. Laboratory diagnosis of invasive candidiasis. Clin Microbiol Rev 1990; 3: 32-45.

3. Wey SB, Mori M, Pfaller MA, Woolson RF, Wenzel RP. Hospital-acquired candidemia. The attributable mortality and excess length of stay. Arch Intern Med 1988; 148: 2642-2645.

4. Buchman TG, Rossier M, Merz WG, Charache P. Detection of surgical pathogens by in vitro DNA amplification. Part 1. Rapid identification of Candida albicans by in vitro amplification of a fungus-specific gene. Surgery 1990; 108: 338-347.

5. Magee BB, D'Souza TM, Magee PT. Strain and species identification by restriction fragment length polymorphisms in the ribosomal DNA repeat of Candida species. $J$ Bacteriol 1987; 169 : 1639-1643.

6. Scherer S, Stevens DA. A Candida albicans dispersed, repeated gene family and its epidemiologic applications. Proc Natl Acad Sci USA 1988; 85: 1452-1456.

7. Sadhu C, McEachern MJ, Rustchenko-Bulgac EP, Schmid J, Soll DR, Hicks JB. Telomeric and dispersed repeat sequences in Candida yeasts and their use in strain identification. J Bacteriol 1991; 173: 842-850.

8. Cutler JE, Glee PM, Horn HL. Candida albicans- and Candida stellatoidea-specific DNA fragment. J Clin Microbiol 1988; 26: 1720-1724.

9. Soll DR, Galask R, Isley $S$ et al. Switching of Candida albicans during successive episodes of recurrent vaginitis. $J$ Clin Microbiol 1989; 27: 681-690.

10. Fox BC, Mobley HLT, Wade JC. The use of a DNA probe for

epidemiological studies of candidiasis in immunocompromised hosts. J Infect Dis 1989; 159: 488-494.

11. Cryer DR, Eccleshall R, Marmur J. Isolation of yeast DNA. Methods Cell Biol 1975; 12: 39-44.

12. Herrmann BG, Frischauf A-M. Isolation of genomic DNA. In : Berger SL, Kimmel AR (eds) Guide to molecular cloning techniques. Methods in enzymology, vol 152. New York, Academic Press. 180-182.

13. Jenkinson HF, Schep GP, Shepherd MG. Cloning and expression of the 3-isopropylmalate dehydrogenase gene from Candida albicans. FEMS Microbiol Lett 1988; 49 : 285-288.

14. Cannon RD, Jenkinson HF, Shepherd MG. Isolation and nucleotide sequence of an autonomously replicating sequence $(A R S)$ element functional in Candida albicans and Saccharomyces cerevisiae. Mol Gen Genet 1990; 221 : 210-218.

15. Rigby. PWJ, Dieckmann M, Rhodes C, Berg P. Labeling deoxyribonucleic acid to high specific activity in vitro by nick translation with DNA polymerase I. J Mol Biol 1977; 113: 237-251.

16. Dorn GL, Smith $\mathrm{K}$. New centrifugation blood culture device. J Clin Microbiol 1978; 7: 52-54.

17. Telenti A, Roberts GD. Fungal blood cultures. Eur $J$ Clin Microbiol Infect Dis 1989; 8: 825-831.

18. Kiehn TE. Bacteremia and fungemia in the immunocompromised patient. Eur J Clin Microbiol Infect Dis 1989; 8: 832-837.

19. Bryan CS. Clinical implications of positive blood cultures. Clin Microbiol Rev 1989; 2: 329-353.

20. Rubino S, Muresu R, Rappelli $P$ et al. Molecular probe for identification of Trichomonas vaginalis DNA. J Clin Microbiol 1991; 29: 702-706. 